\title{
EFEK LATIHAN PLIOMETRIK TERHADAP PERUBAHAN TINGGI LOMPATAN PEMAIN BOLA VOLI
}

\author{
The effect of plyometric training on changes in the jump height of Volleyball Players \\ Darwis Durahim, Anwar Sarman \\ Jurusan Fisioterapi Polteknik Kesehatan Makassar
}

Email: darwis.durahim69@gmail.com

\begin{abstract}
ABSTRAK
Pengaruh latihan pliometrik terhadap perubahan tinggi lompatan Pemain Bola Voli . Penelitian ini bertujuan mengetahui pengaruh latihan pliometrik terhadap perubahan tinggi lompatan Pemain Bola Voli. Jenis penelitian yang digunakan adalah Quasy-experimental dengan menggunakan desain penelitian one-group pretest posttest design dengan variabel independent adalah Latihan fisik dan variabel dependent adalah tinggi lompatan. Teknik pengambilan sampel menggunakan teknik purposive sampling dengan jumlah sampel 30 orang yang dibagi dalam 2 kelompok masingmasing 15 orang dalam kelompok perlakuan dan 15 orang dalam kelompok kontrol. Penentuan sampel berdasarkan kriteria inklusi dan eksklusi. Instrumen pengambilan data yang digunakan dalam penelitian ini adalah vertikal jump test. Penelitian ini dilakukan selama 3 bulan, 16 Juni - 16 September 2020 di SMP Negeri 11 Makassar.
\end{abstract}

Kata Kunci : Latihan Pliometrik, tinggi lompatan, bola volli

\section{ABSTRACT}

The effect of plyometric training on changes in the jump height of Volleyball Players. This study aims to determine the effect of plyometric training on changes in the jump height of volleyball players. This type of research is Quasyexperimental using one-group pretest-posttest design research with the independent variable is physical exercise and the dependent variable is the height of the jump. The sampling technique used purposive sampling technique with a total sample of 30 people divided into 2 groups, each of which was 15 people in the treatment group and 15 people in the control group. The samples were determined based on inclusion and exclusion criteria. The data collection instrument used in this study was the vertical jump test. This research was conducted for 3 months, 16 June - 16 September 2020 at SMP Negeri 11 Makassar.

Keywords: Plyometric Exercise, jump height, volleyball

\section{PENDAHULUAN}

Pada dasarnya manusia dalam melaksanakan olahraga mempunyai tujuan yang berbeda, terdapat empat tujuan tersebut dimana kegiatan olahraga untuk rekreasi, olahraga untuk mencapai tujuan pendidikan, olahraga untuk penyembuhan penyakit dan olahraga untuk prestasi yang setinggi-tingginya. Salah satu olahraga yang terkenal dan banyak digemari di Indonesia bukan hanya karna memiliki banyak ajang perlombaan tetapi juga dapat dimainkan semua kalangan adalah Bola Voli (Pujiarti, 2015). Dalam permainan bola voli setidaknya ada 4 teknik dasar yang harus di kuasai. Teknik tersebut ialah; teknik dasar mempassing bola, mensmes bola, membendung bola dan menservis bola (Faruq, 2009).

Pemain bola voli haruslah di dukung dengan kondisi fisik yang baik agar lebih mudah dalam menguasai teknikteknik dalam permainan bola voli. Adapun komponen latihan fisik dalam permainan bola voli yang sangat perlu untuk dikembangkan dibagi menjadi empat kategori yakni daya tahan, kecepatan, kekuatan dan daya ledak otot (power). Salah satu komponen kondisi fisik yang terpenting adalah Power. Dimana power seringkali membuat perbedaan dalam permainan bola voli terutama dalam pukulan, dan Ioncatan pada saat Smash maupun blok.

Smash yang dilakukan terutama dalam mencapai hasil yang optimal memerlukan daya ledak otot tungkai yang baik sehingga menghasilkan daya lompatan yang tinggi menjadi stabil dan itu memudahkan untuk melakukan Smash. Begitupun sebaliknya jika daya ledak otot tungkai yang kurang baik, maka menyebabkan lemahnya daya lompatan, menyusahkan dalam melakukan Smash. Karna itulah power pemain yang baik sangat dibutuhkan pada permainan bola voli.

Plyometric merupakan bentuk metode latihan untuk mengembangkan kondisi fisik seperti daya tahan, kecepatan, kekuatan dan power. Plyometric ditujukan kepada latihan yang menggunakan 
pergerakan otot-otot untuk menahan beban ke atas dan menghasilkan power atau kekuatan eksplosif. Seperti yang disebutkan sebelumnya bahwa peningkatan daya ledak. otot (power) sangat dibutuhkan oleh pemain voli terlebih kaitannya dengan tinggi lompatan. Tinggi lompatan sangat dibutuhkan pada permainan bola voli terlebih saat melakukan teknik Smash dan block. Sehingga penentuan latihan pliometrik yang sesuai akan sangat efektif dalam meningkatkan daya ledak otot pemain sehingga dapat melakukan teknik dengan baik.

Pliometrik dapat memicu terjadinya Stretch-Shortening Cycle pada otot, yang kemudian akan menginervasi muscle spindle lalu akan diteruskan sampai ke tulang belakang sampai terjadi fase selanjutnya yakni fase concentric, yang pada akhir fase akan menghasilkan adaptasi neuromuscular sehingga daya ledak otot dapat meningkat dan diikuti juga oleh peningkatan tinggi lompatan.

Selain itu terjadinya cidera pada atlet bisa membuat performa dan kepercayaan atlet menurun sehingga selain belum diterapkannya latihan yang sesuai dengan pengembangan kondisi fisik yang diinginkan, dalam hal ini untuk peningkatan tinggi lompatan namun juga dikarenakan hal tersebut dapat menyebabkan resiko cidera atlet sehingga peneliti merasa perlu untuk penentuan program latihan yang sesuai. Selain itu diperlukannya tinggi lompatan yang baik dalam mendukung performa permainan baik saat melompat tinggi ataupun mendarat agar dalam posisi aman.

\section{METODE}

\section{Desain dan Waktu Penelitian}

Jenis penelitian yang digunakan dalam penelitian ini adalah penelitian Quasy Eksperimen. Dengan desain penelitian mengacu pada pre test post tes two control group design. Penelitian dilaksanakan pada 16 Juni - 16 September 2020 di SMPN 11 Makassar.

\section{Populasi dan Sampel}

Populasi Penelitian adalah semua pemain bola volli SMPN 11 Makassar. Sampel penelitian adalah pemain SMP Negeri 11 Makassar sebanyak 30 orang yang dibagi dalam 2 kelompok masing- masing 15 orang untuk kelompok perlakuan dan 15 orang untuk kelompok kontrol. Pengambilan sampel berdasarkan kriteria inklusi dan kriteria eksklusi. Kriteria inklusi berupa jenis kelamin laki-laki, berusia 12 15 tahun dan kriteria eksklusi berupa sakit, cedera.

\section{Instrumen Pengumpulan Data}

Alat atau instrumen yang digunakan untuk mempermudah proses pengumpulan data dalam penelitian ini adalah tinggi lompatan menggunakan vertikal jump test.

\section{Analisa Data}

Data penelitian yang diperoleh sesuai dengan prosedur penetian disusun dan dianalisis secara statistik. Berdasarkan hipotesis yang dirumuskan serta tujuan penelitian nampak bahwa untuk mengetahui Pengaruh latihan pliometrik terhadap perubahan tinggi lompatan Pemain bola voli di SMP Negeri 11 Makassar, maka dilakukan analisis data secara komputerized.

\section{HASIL}

Intervensi yang diberikan kepada sampel, untuk kelompok perlakuan adalah latihan pliometrik dan latihan rutin yang dilakukan di sekolah sedangkan untuk kelompok kontrol adalah latihan rutin yang dilakukan di sekolah. Sebelum dilakukan intervensi terlebih dahulu dilakukan pretest untuk menilai tinggi lompatan sebelum diberikan perlakuan. Intervensi diberikan 2 kali seminggu selama 2 bulan, dan pada intervensi terakhir dilakukan pengkuran kembali untuk menilai perubahan tinggi lompatan sebagai hasil dari post test.

Tabel 1 menunjukkan bahwa pemain volli seluruhnya berjenis kelamin laki-laki, baik kelompok perlakuan maupun kelompok kontrol.

Tabel 2 menunjukkan bahwa pemain bola volli adalah pada kelompok perlakuan yang yang paling banyak berumur 12 tahun dan 14 tahun sebanyak 5 orang (33,3\%). Sedangkan pada kelompok kontrol yang paling banyak adalan umur 13 tahun sebanyak 11 orang (73,3\%).

Tabel 3. menunjukkan bahwa pemberian latihan pliometrik didapatkan mean nilai pretest sebesar 42,00 $\pm 8,089$, nilai posttest sebesar $48,33 \pm 8,608$, dan nilai $p$ sebesar 0,001 atau $<0,05$. Ini berarti ada perbedaan pengaruh nilai tinggi 
lompatan sebelum dan sesudah pemberian latihan pliometrik pada frekuensi 2 kali seminggu selama 2 bulan dengan nilai $p=$ $0,000<0,05$. Artinya pemberian latihan pliometrik mempunyai pengaruh terhadap peningkatan tinggi lompatan.

Tabel 4. menunjukkan bahwa latihan mandiri didapatkan mean nilai pretest sebesar $42,07 \pm 4,978$, nilai posttest sebesar $45,13 \pm 5,125$, dan nilai $p=0,001$ atau $<0,05$. Ini berarti ada perbedaan pengaruh nilai tinggi lompatan pre test kelompok kontrol dengan frekuensi 2 kali seminggu selama 2 bulan dengan nilai $p=0,001<0,05$. Artinya latihan rutin tanpa diberikan latihan pliometrik mempunyai pengaruh terhadap peningkatan tinggi lompatan.

Tabel 5. menunjukkan hasil uji Man Whitney untuk pengujian hipotesis, mulai dari nilai post tinggi lompatan diperoleh nilai $p=0.009<0,05$ yang berarti bahwa ada perbedaan pengaruh yang signifikan antara pemberian latihan pliometrik dengan latihan standar dalam hal ini latihan pliometrik lebih baik dibandingkan tanpa diberikan latihan pliometrik.

\section{PEMBAHASAN}

Pada latihan diperlukan sinkonisasi dimana pelatihan merupakan proses kombinasi yang tepat antara pemberian beban kerja (work load) dan masa istirahat untuk pemulihan. Beban kerja itu berupa tugas-tugas latihan yang berfungsi sebagai stress dan membangkitkan daya adaptasi fungsi psikobiologis. Akibat pembebanan kerja adalah kelelahan, dan disusul proses pemulihan. Hanya melalui prinsip (overload) atau pembebanan yang selalu meningkat secara bertahap akan menghasilkan overkompensasi dalam kemampuan biologik, dan keadaan itu merupakan prasyarat untuk peningkatan prestasi. Karena itu, bisa terjadi beban itu terlampau ringan, jauh dibawah demand yang sesungguhnya. Sebaliknya, bila proses pembebanan itu berlebihan maka akan terjadi (overtraining), dengan akibat kontraproduktif. Semakin dipaksakan atlet menjalani program itu, prestasinya malah kian menurun.

Selain itu Overkompensasi mengacu kepada dampak latihan dan regenerasi pada organisme tubuh kita yang merupakan dasar biologis. Selama masa istirahat ini, sumber-sumber energy biokemikal bukan saja diganti/ dikompensasi, namun akan pula meningkat sampai melewati keadaan dan tingkat kondisi semula. Kalau masa istirahatnya berlangsung terlalu lama, maka overkompensasi akan memudar atau menghilang sama sekali sehingga akan terjadi proses yang disebut involusi. Fase involusi adalah fase perkembangan yang amat minim dari kemampuan peforma kita. Apabila pada fase yang optimal, yaitu pada tahap overkompensasi ini, tubuh tidak diberikan stimulus atau rangsangan lain, maka akan terjadi involusi. Karena itu, jika latihannya tidak dilakukan secara kontinu maka potensi peforma lama-kelamaan akan menurun.

Melihat teori dasar inilah dan juga hilangnya fase recovery dikarenakan sampel yang bersangkutan mengikuti latihan lain diluar program latihan peneliti dikarenakan memepersiapkan diri dalam mengikuti pertandingan, maka dapat terjadi penurunan hasil vertical jump test .Pada penelitian ini, parameter pengukuran pengaruh latihan pliometrik hurdle hopping terhadap perubahan tinggi lompatan yakni menggunakan alat ukur vertival jump test. Sampel yang diambil mengikuti kriteria inklusi yang telah ditetapkan peneliti, yakni yang dapat dijadikan sebagai sampel penelitian adalah subjek penelitian yang bersedia diteliti dan menandatangani informed concern, jenis kelamin laki-laki, mengikuti latihan 2 kali seminggu selama 2 bulan. Pada tabel 5.3 diperoleh data bahwa ada pengaruh sebelum dan setelah diberi latihan pliometrik terhadap nilai tinggi lompatan pada pemain bola voli dengan nilai $p=0,000$ dan perubahan sebesar 6,33. Hasil penelitian ini sejalan dengan penelitian yang dilakukan oleh (Ita \& Guntoro, 2018) yang mengatakan adanya peningkatan daya ledak otot setelah pemberian latihan pliometrik.

Penelitian ini sejalan dengan penelitian yang dilakukan oleh Putra (2017) yang menyatakan latihan pliometrik terbukti berpengaruh terhadap tinggi lompatan. Penelitian ini juga sejalan dengan penelitian yang dilakukan oleh Khadarisman (2018) yang menyatakan Latihan pliometrik dapat mempengaruhi tinggi lompatan dikarenakan pliometrik dapat meningkatkan aktivitas reaksi gaya saraf. Peningkatan lompatan pada responden juga dikarenakan latihan pliometrik menerapkan FITT dengan meningkatkan beban dalam beberapa periode. 
Penelitian ini juga sejalan dengan penelitian yang dilakukan oleh Rahman et.al (2018) yang menyatakan latihan power menggunakan metode pliometrik dapat meningkatkan lompatan smash pada atlet UKM voli putri.

Peningkatan hasil yang terjadi tidak lepas dari dasar fisiologis proses sistem kerja pada latihan pliometrik yakni sistem neuromuscular. Seperti yang diungkapkan Kisner et.al (2017) dimana pada adaptasi saraf akan terjadi proses motor learning dan improved coordination dimana akan terjadi peningkatan jumlah motor unit, kecepatan hantar saraf, dan sinkronisasi dari gerakan. Dalam hal ini perubahannya disebabkan karena penurunan fungsi inhibisi dari system saraf pusat, menurunnya sensitifitas dari organ golgi tendon. Selain itu juga terjadi adaptasi serabut otot yakni hipertrofi. Hipertrofi adalah peningkatan ukuran pada serabut otot yang disebabkan kerena adanya peningkatan volume pada myofibril. Mekanisme hipertrofi akan terjadi peningkatan jumlah sintesis protein (aktin dan myosin) dan penurunan degradasi protein, dimana akan terjadi perubahan biokimia pengambilan asam amino. Inilah yang disebut adaptasi Neuromuscular. Pada saat melakukan latihan pliometrik, perubahan karakteristik kontraksi otot kekuatan-kecepatan yang disebabkan oleh peregangan (Stretch) dari gerakan Concentric (pemendekan) dengan menggunakan Stretch Reflex. Bagian Reflexive latihan pliometrik terutama pada aktivitas Muscle Spindle. Muscle Spindle ialah organ proprioseptif yang sensitif terhadap tingkat dan besarnya peregangan. Selama latihan pliometrik Muscle Spindle dirangsang oleh peregangan yang cepat menyebabkan kerja otot yang Reflexive. Tiga fase utama pada Stretch Reflex ialah pada fase pertama Fase Eccentric adalah fase meregangkan kelompok agonis. Selama fase ini energi elastisitas disimpan dalam komponen rangkaian dan Muscle Spindle dirangsang. Hal tersebut dikarenakan ketika otot dengan cepat diregangkan, serangkaian komponen elastik ini juga meregang, sehingga menyimpan suatu bagian kekuatan beban dalam berenergi potensial elastic. Pemulihan enegi elastik yang tersimpan terjadi selama fase Eccentric atau penguasaan kontraksi otot, yang dipicu oleh refleks myotatic. Selain itu Muscle
Spindle yang meregang mengirim sinyal ke akar bagian perut dari sumsum tulang belakang melalui serabut afferent. Diikuti fase kedua yakni faase amortisasi dimana fase ini menandakan berakhirnya fase Eccentric dan menuju fase Concentric. Selama fase ini alpha neuron motorik mengirimkan sinyal ke otot agonis. Fase ini merupakan fase transisi dari Eccentric ke Concentric dengan cepat dan tanpa gerakan. Pada fase ini daya ledak yang besar dapat diperoleh dengan mempertimbangkan durasi fase yang sesingkat mungkin akan jauh lebih baik. Fase Concentric mengikuti fase Amortisasi yang terdiri pada saat pendaratan sampai atlet melakukan lompatan atau kaki atlet meninggalkan permukaan. Energi yang sebelumnya tersimpan akan dilepaskan pada fase Concentric dikarenakan energy tersebut akan kembali digunakan untuk mengulang fase stretch reflex. Teori fisiologis tersebut mendukung hasil penelitian yang dipaparkan pada tabel sebelumnya dimana latihan pliometrik yang akan merangsang muscle spindle dan golgi tendon sehingga menyebabkan adaptasi neuromuscular sehingga terjadinya stretch reflex yang jika rutin dilakukan dalam kurun waktu yang ditentukan akan menyebabkan terjadinya perubahan tinggi lompatan pada pemain yang dilatih. Latihan Plyometric memiliki kelebihan pada peningkatan Vertical Jump seorang atlet yang mana akan mendukung dalam peningkatan performa permainan bola voli yang membutuhkan loncatan horisontal yang tinggi seperti yang dibutuhkan pada saat melakukan penyerangan (Smash) dan pertahanan (blok). Hal tersebut sejalan dengan penelitian yang dilakukan Kalfi (2013) dimana mengatakan adanya peningkatan yang signifikan pada kelompok eksperimen hurdle hopping ini karena pada saat pemberian treatment seorang atlet di tuntut lebih extra dalam melakukan loncatan horisontal maksimal dalam melewati rintangan atau gawang yang diloncati. Latihan plyometric hurdle hopping memiliki kelebihan pada peningkatan vertical jump seorang atlet yang mana akan mendukung dalam peningkatan performa permainan bola voli yang membutuhkan loncatan horisontal yang tinggi seperti yang dibutuhkan pada saat melakukan penyerangan (smash) dan pertahanan (blok). Karena itulah gerakan ini sangat 
diperlukan dalam cabang olahraga bola voli.

\section{KESIMPULAN DAN SARAN}

Kesimpulan dalam penelitian ini adalah terjadi perubahan tinggi lompatan pada pemain bola volli pada pemberian latihan pliometrik, terjadi perubahan tinggi lompatan pada pemain bola volli pada kelompok kontrol yang melakukan latihan secara mandiri, perubahan tinggi lompatan pada kelompok yang diberikan latihan pliometrik lebih baik dibandingkan kelompok kontrol yang melakukan latihan mandiri.

Saran yang dapat dikemukakan oleh peneliti adalah: tinggi lompatan pada pemain volli dapat diatasi oleh fisioterapi berupa latihan pliometrik, sebaiknya dalam melakukan penelitian lebih memperhatikan homogenitas responden agar hasil yang diperoleh menjadi lebih baik serta memilih responden yang lebih dapat terkontrol agar hasil yang diperoleh lebih nyata.

\section{DAFTAR PUSTAKA}

Faruq, M. M. (2009). Meningkatkan Kebugaran Melalui Bola Voli. Grasindo.

Ita, S., \& Guntoro, T. S. (2018). The effect of Plyometric and Resistance training on Muscle Power, strength, and speed in Young Adolescent soccer Players. Indian Journal of Public Health Research \& Development, 9(8), 1450-1455.

Kalfi, R. (2013). Pengaruh Latihan Plyometric Hurdle Hopping dan Depth Jump terhadap
Peningkatan Vertical Jump Bola Voli Club JIB Kids Bantul. Skripsi. Yogyakarta: Universitas Negeri Yogyakarta.

Khadarisman, D. F. (2018). Pengaruh Latihan Pliometrik Double Leg Bound di Pasir terhadap Tinggi Lompatan pada Pemain Bolavoli Putra UABV Universitas Negeri Malang. SKRIPSI Jurusan IImu Keolahragaan-Fakultas IImu Keolahragaan UM.

Kisner, C., Colby, L. A., \& Borstad, J. (2017). Therapeutic exercise: foundations and techniques. Fa Davis.

Pujiarti, S. (2015). Pengaruh Latihan Hurdle Hops Dalam Peningkatan Daya Ledak Otot Tungkai Pesilat Remaja (Eskperimen pada Pesilat Remaja Persatuan Seni Beladiri Garuda Sakti Kota Pekalongan Tahun 2014). Universitas Negeri Semarang.

Putra, R. (2017). Pengaruh Latihan Pliometrik (Jump To Box) Dan Latihan Skipping Terhadap Tinggi Lompatan Siswa Ekstrakurikuler Sepak Bola Sma Negeri 5 Bandar Lampung.

Rahman, A., Simanjuntak, V. G., \& Hidasari, F. P. (2018). Pengaruh Latihan Power Menggunakan Metode Pliometrik Terhadap Lompatan Di UKM Voli Untan. Jurnal Pendidikan Dan Pembelajaran Khatulistiwa, 7(7). 


\section{LAMPIRAN}

Tabel 1. Distribusi responden berdasarkan jenis kelamin

\begin{tabular}{lccccc}
\hline Jenis Kelamin & \multicolumn{2}{c}{$\begin{array}{c}\text { Kelompok Perlakuan } \\
\text { Latihan pliometrik }\end{array}$} & \multicolumn{2}{c}{ Kelompok Kontrol } \\
\cline { 2 - 5 } & $\mathrm{f}$ & $\%$ & $\mathrm{f}$ & $\%$ \\
\hline Laki-laki & 15 & 100,0 & 15 & 100,0 \\
\hline Total & 15 & 100,0 & 15 & 100,0 \\
\hline
\end{tabular}

Tabel 2. Distribusi responden berdasarkan umur

\begin{tabular}{lcccc}
\hline Umur & \multicolumn{2}{c}{ Kelompok Perlakuan } & \multicolumn{2}{c}{ Kelompok Kontrol } \\
\cline { 2 - 5 } & $\mathrm{f}$ & $\%$ & $\mathrm{f}$ & $\%$ \\
\hline 12 tahun & 5 & 33,3 & 2 & 13,3 \\
13 tahun & 4 & 26,7 & 11 & 73,3 \\
14 tahun & 5 & 33,3 & 1 & 6,7 \\
15 tahun & 1 & 6,7 & 1 & 6,7 \\
\hline Total & 15 & 100,0 & 15 & 100,0 \\
\hline
\end{tabular}

Tabel 3. Nilai tinggi lompatan pemain volli sebelum dan sesudah pemberian latihan pliometrik

\begin{tabular}{cccc}
\hline Pengukuran tinggi lompatan & mean & SD & $p$ \\
\hline Pre test & 42,00 & 8.089 & \\
\cline { 1 - 2 } Post test & 48,33 & 8,608 & 0,001 \\
\hline
\end{tabular}

Ket : uji wilcoxon

Tabel 4. Nilai tinggi lompatan pemain sebelum dan sesudah latihan mandiri kelompok kontrol di SMP Negeri 11 Makassar

\begin{tabular}{cccc}
\hline Pengukuran tinggi lompatan & mean & SD & $p$ \\
\hline Pre test & 42,07 & 4.978 & \\
\cline { 1 - 2 } Post test & 45,13 & 5,125 & 0,001 \\
\hline
\end{tabular}

Ket : uji wilcoxon

Tabel 5.Analisis perbandingan perubahan tinggi lompatan pemain antar kelompok perlakuan dengan kelompok kontrol

\begin{tabular}{lcc}
\hline \multicolumn{1}{c}{ Pengukuran } & Mean & P \\
\hline Selisih pretes dan post test kelompok perlakuan & 6,33 & \\
\cline { 1 - 1 } Selisih pretes dan post test kelompok kontrol & 3,06 & 0.009 \\
\hline
\end{tabular}

Ket : Uji Man-Whitney 